\title{
Challenges of Implementing Technology in ESL Writing Classrooms: A Case Study
}

\author{
Basim Alamri ${ }^{1}$ \\ ${ }^{1}$ English Language Institute, King Abdulaziz University, Jeddah, Saudi Arabia \\ Correspondence: Basim Alamri, English Language Institute, King Abdulaziz University, Jeddah, Saudi Arabia.
}

Received: October 24, 2021

Accepted: November 15, 2021

Online Published: November 17, 2021

doi: $10.5539 /$ elt.v14n12p36

URL: https://doi.org/10.5539/elt.v14n12p36

\begin{abstract}
The present study aimed to investigate the challenges and barriers encountered by ESL teachers when they implement technological tools in writing classroom. It also explored teachers' perceptions towards integrating technology in writing classroom. The study involved observing a number of writing classes from different levels at an English Language Institute at a southwestern university in the United States. Next, an interview was conducted with one of the observed teachers to enquire about implementing technology in the classroom and reasons behind possible challenges. The study revealed some challenges that hindered or prevented teachers from applying technology in writing classroom. Such challenges were technical problems, students' attitudes towards using technology, lack of time, lack of computers and other devices, and lack of technical support. Moreover, the study showed that teachers had positive perceptions toward using technology to facilitate teaching process. Pedagogical implications and solutions to overcome technical issues are provided for ESL/EFL writing teachers and policy makers.
\end{abstract}

Keywords: barriers, challenges, ESL writing classroom, Web 2.0, technology

\section{Introduction}

The use of technology in education has grown rapidly in recent years (Al-Wasy, 2020). Teaching writing is often considered as challenging; thus, teachers and students are encouraged to integrate technological tools such as Web 2.0 or 3.0 in their classrooms. These tools are well-developed to be used with any skills, and they are freely available and accessible in many universities. Furthermore, teachers and students nowadays carry their laptops, tablets, and cellphones, in which these devices have numerous applications and features installed to be used in teaching-learning process, such as the Internet. The Internet has caused a significant change in teachers' perspective in a way that the teaching tools offered through the Internet are increasingly becoming more reliable. Nowadays, the Internet is attaining enormous popularity in second and foreign language teaching, and more educators and learners are embracing it ( $\mathrm{Lu}, 2006)$. In writing skills, for example, several research studies have been conducted to determine whether the use of technology in the teaching-learning process has improved learner performance (Al-Wasy, 2020; Bikowski \& Vithanage, 2016).

The term technological tools has been defined in light of how these tools and their roles are implemented in the classroom. For instance, "Web 2.0," a term coined in 2004, is used to describe the transition from the predominantly read-only Web 1.0 into a "read-and-write" Web 2.0. Other terms used to characterize Web 2.0 and perhaps 3.0 include "social digital technologies" (Greenhow et al., 2009; Palfrey \& Gasser, 2010). A common term which is widely used nowadays is Computer-Assisted Language Learning (CALL). Beatty (2013) broadly defined CALL as "any process in which a learner uses a computer and, as a result, improves his or her language". This definition of CALL accommodates its changing nature. In addition, mobile-assisted language learning (MALL) is considered as a fast-growing subcategory of CALL. The Higher Education association EDUCAUSE (2021) defines MALL as:

"Using portable computing devices (such as iPads, laptops, tablet PCs, PDAs, and smart phones) with wireless networks enables mobility and mobile learning, allowing teaching and learning to extend to spaces beyond the traditional classroom. Within the classroom, mobile learning gives instructors and learners increased flexibility and new opportunities for interaction." 
It is commonly known that many teachers are not using technology for various reasons. As I am an educator, who met a number of teachers whom they did not use technology, they, fortunately, provided me with some reasons. For instance, some teachers may lack the knowledge of how to implement technology. Moreover, the teachers who have had training may still lack the confidence to use it. Others may not recognize the value that technology can benefit their teaching processes. Honestly, such reasons could be expected, yet, in this paper, I still need to hear from the teachers themselves, and perhaps from students in the future. Such questions worth asking are: How do these teachers feel about implementing technology in their classrooms? How do their beliefs influence their use of technology? Why do not they implement technology in the classroom? These questions could arise to any researchers' attention when they attempt to investigate implementing technology in the classroom. Yet, it does not necessarly mean that we (as researchers) place the blame upon teachers for not using technology. Here, the need for teachers' perceptions of implementing technology would help overcome challenges and barriers that prevent teachers from taking advantage of technology.

As a part of a large project, the current small-scale case study focused on obstacles and challenges of implementing technological tools in the classroom to develop ESL writers' skills. The purpose of this qualitative study was to obtain a better understanding of language teachers' beliefs and perceptions about implementing technology in the classroom. Moreover, the study aimed to identify challenges that encounter, and sometimes prevent, teachers from implementing technology in the classroom.

To do so, the study involved observing a number of writing classes from different levels at an English Language Institute at a southwestern university in the United States (U.S.). Next, an interview was conducted with a teacher who was observed to ask her general and specific questions about the observation. The study attempted to answer the following research questions:

1) How do teachers perceive implementing technology in their classrooms?

2) What are the challenges, if any, encounter ESL teachers when implementing technology in ESL writing classroom?

3) What are some solutions offered by ESL teachers to overcome issues when implementing technology in ESL writing classroom?

\section{Literature Review}

Several research studies have been carried out to investigate implementing technology in an ESL writing classroom. The studies have revealed a number of general advantages and drawbacks of the implementation (An \& Williams, 2010; Nim Park \& Son, 2009; Riasati et al., 2012). Others focused specifically on using Web 2.0 tools to teach online writing (Jun \& Lee, 2012; Laire et al., 2012; Miyazoe \& Anderson, 2010; Yunus et al., 2013). Some studies also focused only on providing benefits of implementing technology in the writing classroom in different disciplines (Kutlu, 2013). In an ESL context, most studies investigated the effect of technological tools on students' writing (Al-Wasy, 2020; Bikowski \& Vithanage, 2016; Tze Pheng et al., 2021).

In an experimental study, Bikowski \& Vithanage (2016) investigated the effectiveness of an in-class web-based collaborative writing task with 59 students in U.S. university. The results of the study revealed positive impact of using this technology tool in writing classrooms. Similarly, in a meta-analysis study, Al-Wasy (2020) analyzed 18 empirical studies to investigate the effectiveness of integrating technology in EFL/ESL writing classrooms. Overall, the results indicated that technology tools had significant impact on ESL/EFL students writing skills. The study also reported that there have been more studies relating to implementing technology tools were conducted in EFL context compared to ESL context, which calls for mor studies in this area.

Relating to general benefits and drawbacks, An and Williams (2010) conducted a qualitative study to explore the advantages and barriers of integrating Web 2.0 technologies in the classroom. The authors used a survey with open-ended questions that was distributed to a number of professors in different universities in the United States. The findings revealed advantages and disadvantages of Web 2.0. As for the former, the major advantages were 'interaction, communication and collaboration', 'knowledge creation, ease of use and flexibility', 'writing and technology skills' (p. 44). Whereas the latter, the drawbacks were 'uneasiness with openness', 'technical problems', and 'time' (p. 45). Interestingly, the participants reported that implementing Web 2.0 tools helped students improve their writing skills. Meanwhile, the study did not provide any barriers relating to using technology in a writing classroom.

Similarly, benefits and barriers were discussed by Riasati et al. (2012). The authors provided various reasons that led teachers and students to implement technology in the classroom. These advantages and barriers were focused on implementing technology in all language skills (i.e. reading, writing, listening, speaking) obtained from 
several research studies. The benefits were engagement, improvement in academic ability, a paradigm shift in teaching and learning, an assessment shift, collaborative learning enhancement, lowering learning anxiety level. On the other hand, the barriers included a lack of access, a lack of effective training, teachers' attitude, students' attitude, a lack of time, and technical support.

Likewise, Park and Son (2009) investigated teachers' perceptions and perspectives towards implementing Computer-Assisted Language Learning (CALL) in the classroom. A questionnaire and follow-up interviews were employed to collect data. The results of the study showed that the teachers had positive attitudes toward the use of computers. The teachers considered computer technology as a useful teaching tool because it enhanced various ways of teaching by providing students a variety of knowledge and information to expand students' learning experiences in real and authentic contexts. The study also reported some external factors that negatively influenced the implementation of CALL in the classroom: a lack of time, rigid school curricula and textbooks, insufficient computer facilities, and a lack of administrative support. Furthermore, internal factors included teachers' limited computer skills, knowledge about computers and beliefs and perceptions of CALL.

Relating to online writing, Jun and Lee (2012) conducted a study to analyze a three-week online ESL writing unit on the compare-and-contrast essay type. Basically, the unit contained different types of assignments that were similar to the ones provided onsite, yet these assignments were modified to be easily integrated into an online environment. The unit incorporated several technologies and resources in order to take advantage of them. Questionnaires and semi-structured interviews were applied to collect data from international undergraduate students. The findings revealed that some benefits obtained from online writing classes were the students' use of language and the enjoyment of exchanging comments. However, teachers and students reported some challenges such as: "the inconvenience of providing feedback in the Moodle system and the difficulty of a few tasks for the students" (p. 130). Moreover, some teachers experienced difficulties when using technology that caused frustration which consequently hinder teaching the students.

Storify, one of the Web 2.0 tools, has been widely implemented in writing classroom. Lairea et al. (2012) conducted a study to examine the effectiveness of integrating social media in the writing classroom. The researchers focused particularly on Storify; it "prompts writing a story by adding text to the existing information, drawn from various social networks, thus generating numerous writing possibilities" (p. 444). The instruments used to collect data included a specific lesson taught by using Storify, surveys, and detail description from the teachers after the lesson was administered to students. The study showed that storify enhanced students' writing skills. On the other hand, teachers encountered some challenges, such as "limited computer equipment and access, incompatible servers and unbreakable firewalls", and a matter of limited time (p. 447). Also, the teachers reported that some students were reluctant to use their personal Facebook account in this lesson.

Correspondingly, Miyazoe and Anderson (2010) examined the effectiveness of three different online writing activities at Tokyo University: forums, blogs, and wikis. The authors designed an online writing blended course to teach writing by using the three tools. After providing instruction about using these tools, the authors used a mixed method approach (i.e., survey, interview, and written assignments) to collect data. The findings revealed that students had positive perceptions towards the blended course. They also reported some advantages and preferences for selecting one tool among others. Students' preferences were Wiki, then Blog and lastly forum. In addition, the study showed that students encountered difficulties when they used these tools. For instance, some students did not comment on each other's blog although they were allowed to do so. How to assess collaborative work (i.e., written assignment) was a second challenge encountered by teachers.

In addition, Yunus et al. (2013) investigated the advantages and drawbacks of integrating social media networks tools in ESL writing courses. It also examined different ways of using activities related to social media network. The authors collected data through an online discussion board from TESL students in a state university in Malaysia. The findings revealed several advantages for integrating social media in an ESL writing classroom. For example, the social media networks tools helped enrich students' knowledge, increased their motivation and built confidence in learning ESL writing. On the other hand, students reported that they had difficulties in concentrating on online reading, lacking equipment to access the Internet, and some students played computer games during their spare and lecture time. Furthermore, the relationship between teacher and students could be tricky in this sense, time consuming, and "writing tasks online will lead students to 'copy-paste' from the extensive online resources without thinking" (p. 45).

Lastly, teaching writing through technology has been discussed in the field of English for Specific Purposes (ESP). Kutlu (2013) carried out a research study to examine the effectiveness of implementing technological tools in ESP writing classroom, i.e., business English. The author used tutorial videos, questionnaires, and 
interview to collect data. The findings indicated that technological tools helped students improve their writing skills. Students also were able to write formal e-mails. Unfortunately, the author did not discuss any challenges encountered while conducting the study.

The vast majority of the literature has discussed, in general, implementing technological tools in classrooms. In addition, even though other research studies have investigated advantages and disadvantages of integrating technology in the classroom (An \& Williams, 2010; Nim Park \& Son, 2009; Riasati et al., 2012), they, again, did not focus on challenges or barriers of implementing technology in ESL/EFL writing classroom. The literature also included few studies conducted to investigate integrating technology in ESL writing in high schools and university, for more details: (Kopcha, 2012; Lu, 2006; Salehi \& Salehi, 2012; Tze Pheng et al., 2021). Furthermore, the majority of the studies were quantitative by using surveys or mixed-method approach. The present study employed observations and a semi-structure interview with writing instructors at a university level. That is, the study concentrated on implementing technological tools in ESL writing classrooms at a southwestern university in the United States. The present study is a part of a large project on observing how English writing teacher implement technology in writing classroom. Therefore, the purpose of the study was to investigate the challenges and barriers that encounter ESL teacher when they implement technological tools in a writing classroom. It also aimed to explore teachers' perceptions and strategies towards integrating technology in a writing classroom.

\section{Method}

\subsection{Participants}

The study participants included three ESL instructors ( 2 female, 1 male) at an English Language Institute at a southwestern university. They were aged between 30 and 40. They were native English speakers with teaching experience varied between six and twelve years; 10 years of experience in teaching English to ESL international university students. The instructors hold a master's degree in Teaching English to Speakers of Other Language (TESOL). They taught different courses (reading, writing, grammar) and different levels (beginner, low and high intermediate, advanced). The names of instructors were pseudonyms.

\subsection{Instruments}

The study involved a qualitative case study in order to be close to participants. The reason for applying qualitative method relied on the need to obtain detailed information directly from the participants by observing their performances and then interviewing them to discuss notes from the observations. Therefore, an exploratory case study qualitative research method would help answer questions and follow-up questions that a questionnaire may not provide a chance to explain them.

\subsubsection{Observation}

The five observations were held on at the English Language Institute at a southwestern university. The purpose was to focus on teaching writing for international students (ESL) who were placed on different levels (i.e., lower - two observations, and high intermediate - three observations). Also, it aimed to observe challenges and barriers that encounter instructors when they implement technology in the classroom. Each lecture was 45 minutes in length, and detailed field notes were taken to provide additional information on the classroom context. The observed classrooms focused only on writing skills.

\subsubsection{Interview}

A semi-structured interview was conducted in Ms. Sarah's (pseudonym) office at the English Language Institute at a southwestern. The interview discussed strategies of teaching academic writing in the classroom. It also intended to find out challenges and barriers that encounter ESL teachers when using technology in the classroom. A special cellphone application called Voice Recorder was used to record the interview, and lasted approximately 32 minutes. During the interview, there were several attempts to ensure high-quality recording and reduce noises. Following that, the interview was transcribed. Therefore, a number of questions emerged during the interview in order to obtain clarifications from the interviewee.

\subsection{Data Analysis}

The field notes and the semi-structure interview were analyzed thematically based on the research questions and emerging themes. Such themes included the challenges that ESL teachers encounter when they implement technology in a writing classroom, how they feel about these challenges, and other teaching writing strategies. 


\section{Results and Discussion}

\subsection{Teaching Writing Strategies}

Although not all observed teachers employed technology in writing classroom, they implemented various teaching strategies and techniques. Some examples from the field notes included writing classroom agenda on the board which helped organize the class time, preparing classroom environment occasionally, changing group members from time to time, using visual aids, allotting reasonable time for answering activities especially writing essays, time management, using external resources for students, asking students to write essays about their research interest and not limit them to one particular topic, dealing with students from different cultures, ethnic groups, and countries.

In light of the observations and the interview, the three instructors provided different ways of implementing technological tools in a writing classroom. Previous studies also reported similar findings (An \& Williams, 2010; Riasati et al., 2012; Tze Pheng et al., 2021; Yunus et al., 2013). For instance, Ms. Carla employed Dropbox, Microsoft PowerPoint, Microsoft Word, emails, and the Internet in her classroom. Furthermore, how to teach writing different types of essays and how to provide feedback to students were other useful tips derived from the interview. The results also reported several feedback techniques, such as written and oral, direct and indirect, and teacher-students and peer feedback.

\subsection{Challenges When Implementing Technology in Writing Classroom}

After observing the teachers' classes, I discussed with them why some teachers did not use technology. They reported that they would love to employ technological tools in their classroom. Another teacher stated that he would use technology when he needed it because some lessons did not require using technology.

During the observations, several expected and unexpected issues were observed relating to technology and students' perceptions. As for technological issues, Ms. Carla encountered difficulties when she tried to connect to university Wi-Fi network. She tried to connect to the university Wi-Fi through her personal laptop. Unfortunately, neither her own laptop nor the university laptop was able to connect to the university Wi-Fi. She attempted many times, but they did not work. She planned to download students' assignment from her Dropbox. Finally, she gave up and decided to provide a lesson from the textbook. 25 minutes later, Ms. Carla was still eager to use technology when she asked "can anyone here help me fix this problem" since "there is no time to call IT staff to fix it." After the problem was solved, Ms. Carla used track changes tool in Microsoft Word to show how to correct students' mistakes. She furthermore discussed in detail each mistake, asked students to find out their mistakes, and also came up with correct answer or alternative answer. She advised students "you have to be explicit when you want to clarify or write your arguments." The main mistakes were related to grammatical aspects, ambiguous sentences, words choices, using modals, and connecting words. Another unexpected problem occurred when the teacher finished editing mistakes in a students' writing sample. Meanwhile, the teacher asked students 'Do you like this way of using technology to correct students' mistakes?' The majority of the students answered 'Yes'. However, one student responded by saying ' $N o$ '. The teacher and other students asked the student 'Why?', yet he did not provide any reasons for 'disliking'. Instead, he said 'that's it I don't like it'. Riasite et al. (2012) resonated students' negative attitudes towards technology to the drastic shift the students may experience from using traditional approach to a new one. In this situation, I would not expect such a reaction from students for several reasons. At first, I thought that the edited writing sample belonged to that student; however, when I asked the teacher, she said that all students participated in writing that piece. Regardless, students at this age use technology in their daily life. Therefore, they would enjoy using technology to facilitate their learning process. Also, the technological tools would help students develop their writing proficiency. After the class, the teacher reported to me that what happened was one of the unexpected problems encountered when using technology. Indeed, what happened was an exceptional case that would not matter to be a serious problem nor prevent teachers from implementing technology in the classroom.

During the interview with Ms. Sarah, she said that her colleagues and she had positive perceptions towards technology. However, the teachers reported that they encountered various expected and unexpected problem (i.e., students' attitude as the case with a student in Ms. Carla's class). Ms. Sarah reported some technological issues such as "I have been reluctant to do that [using technology in writing classroom] because every time I want to use a computer something happens ... I spent some time trying to figure it out, why isn't the connection working? Why don't I have internet? Why isn't the speaker working? Where is the projector remote? and things like that." In addition to these technical issues, Ms. Sarah reported issues related to students who have less or no experience in using computer. Such issues include some students don't [know how to use Dropbox]. Some students have had difficulties with the idea of FTP address... I have students who are not familiar with computers at all so I have 
hard time] implementing technology in the classroom, and I have students who don't own the computer. These problems are in line with the ones mentioned in the literature (Al-Wasy, 2020). For instance, the lack of time and technical support, the lack of access and not enough computers, and the lack of adequate training are challenges confronted by writing teachers when employing technology.

\subsection{Solutions to Overcome Technical Issues}

Regardless of the reported issues, the teachers provided instant solutions to solve these issues. For instance, the teachers stated that they asked their students who had difficulties with technology to visit them in their offices to have one-to-one sessions. In response to students who had slow typing skills, Ms. Sarah said I have met them one-on-one and I've helped them create a profile online on free one of those free websites that teach them how to type. As for technological issues, the teachers mentioned that they tried to solve any issues by themselves. However, they reported that some issues needed the information technology (IT) department to solve the issues, as the case with Ms. Sarah's classroom; I teach in this classroom up here [she pointed at the room], there is no internet, the computers are pretty slow, the speakers are not working, the projector is not working. I reported all of that, right. So, I just need to wait for IT to come and fix it.

\section{Conclusion}

The present small-scale qualitative case study has explored some challenges of implementing technology in the ESL writing classroom which were encountered by three ESL teachers in a southwestern university in the USA. The findings reveled that technical problems, students' attitudes towards using technology, the lack of time, the lack of computers and other devices, and the lack of technical support were common challenges. The study hopes to contribute to the field of teaching academic writing ESL and EFL contexts. It would be an excellent opportunity to help the community of practice overcome difficulties that hinder implementing technology in the classroom.

As for pedagogical implications, institutions should equip all classrooms with advanced and up-to-date technological tools in order to provide an appropriate learning environment. The institutions need to provide technical support team as well as training courses for teachers in how to implement technology tools in writing classroom. In response to Mr. Tom's concerns that some lessons do not need implementing technology tools, policy makers have to adapt curriculum and textbooks in writing classrooms to become user-friendly with technology tools.

In addition, observing experienced ESL teachers with higher degrees such as a master's degree in TESOL would definitely benefit other teachers in various ways. For instance, the observation provide opportunity to learn how to apply different teaching techniques, strategies, and ideas in ESL classrooms. Such these strategies include group and pair work, peer and group feedback, class discussion, and implemented technology. All in all, observing experienced teachers practicing these techniques encourages other teachers to employ these techniques as well.

This study has some limitations. The study focuses only on challenges that encounter teachers when integrating technological tools in ESL writing classroom. Future studies are worthwhile to discuss challenges that confront teachers and students in different skills other than writing. Also, various instruments such as questionnaire and using Web 2.0 or 3.0 tools in the classroom would reveal additional challenges and barriers on one hand and provide solutions for the challenges mention here on the other.

\section{Acknowledgments}

Special thanks go to the instructors who agreed to observe their classes and conduct the interview. Also, I would like also to thank my colleagues for their supports and advices.

\section{References}

Al-Wasy, B. Q. (2020). The effectiveness of integrating technology in EFL/ESL writing: A meta-analysis. Interactive Technology and Smart Education, 17(4), 435-454. https://doi.org/10.1108/ITSE-03-2020-0033

An, Y.-J., \& Williams, K. (2010). Teaching with Web 2.0 technologies: Benefits, barriers and lessons learned. International Journal of Instructional Technology and Distance Learning, 7(3), 41-48.

Beatty, K. (2013). Teaching \& Researching: Computer-Assisted Language Learning (2nd ed.). Routledge. https://doi.org/10.4324/9781315833774

Bikowski, D., \& Vithanage, R. (2016). Effects of web-based collaborative writing on individual L2 writing development. Language Learning \& Technology, 20(1), 79-99. Retrieved from https://lt.msu.edu/issues/february2016/bikowskivithanage.pdf 
EDUCAUSE. (2021). Mobile learning. $\quad$ Retrieved from https://library.educause.edu/topics/teaching-and-learning/mobile-learning

Greenhow, C., Robelia, B., \& Hughes, J. E. (2009). Learning, Teaching, and Scholarship in a Digital Age: Web 2.0 and Classroom Research: What Path Should We Take Now? Educational Researcher, 38(4), 246-259. https://doi.org/10.3102/0013189X09336671

Jun, H. G., \& Lee, H. (2012). Student and teacher trial and perceptions of an online ESL academic writing unit. Procedia - Social and Behavioral Sciences, 34, 128-131. https://doi.org/10.1016/j.sbspro.2012.02.026

Kopcha, T. J. (2012). Teachers' perceptions of the barriers to technology integration and practices with technology under situated professional development. Computers \& Education, 59(4), 1109-1121. https://doi.org/10.1016/j.compedu.2012.05.014

Kutlu, Ö. (2013). Using Technology for Developing Writing in an ESP Class. Procedia - Social and Behavioral Sciences, 70, 267-271. https://doi.org/10.1016/j.sbspro.2013.01.064

Laire, D., Casteleyn, J., \& Mottart, A. (2012). Social Media's Learning Outcomes within Writing Instruction in the EFL Classroom: Exploring, Implementing and Analyzing Storify. Procedia - Social and Behavioral Sciences, 69, 442-448. https://doi.org/10.1016/j.sbspro.2012.11.432

Lu, S. (2006). Barriers on ESL CALL Programs in South Texas. Journal of Online Learning and Teaching, 2(3), $158-168$.

Miyazoe, T., \& Anderson, T. (2010). Learning outcomes and students' perceptions of online writing: Simultaneous implementation of a forum, blog, and wiki in an EFL blended learning setting. System, 38(2), 185-199. https://doi.org/10.1016/j.system.2010.03.006

Nim Park, C., \& Son, J.-B. (2009). Implementing Computer-Assisted Language Learning in the EFL Classroom: Teachers' Perceptions and Perspectives. International Journal of Pedagogies and Learning, 5(2), 80-101. https://doi.org/10.5172/ijpl.5.2.80

Palfrey, J. G., \& Gasser, U. (2010). Born digital: Understanding the first generation of digital natives (Rev. with a new afterword). Basic Books.

Riasati, M. J., Allahyar, N., \& Tan, K.-E. (2012). Technology in Language Education: Benefits and Barriers. Journal of Education and Practice, 3(5), 25-30.

Salehi, H., \& Salehi, Z. (2012). Challenges for Using ICT in Education: Teachers' Insights. International Journal of E-Education, e-Business, e-Management and e-Learning, 2(1), 40-43.

Tze Pheng, K., Hashim, H., \& Ainil Sulaiman, N. (2021). The Use of Technology in Teaching of Writing Among Malaysian ESL Secondary School Teachers. Arab World English Journal, 7(1), 314-330. https://doi.org/10.24093/awej/call7.22

Yunus, M., Nordin, N., Salehi, H., Amin Embi, M., \& Salehi, Z. (2013). The Use of Information and Communication Technology (ICT) in Teaching ESL Writing Skills. English Language Teaching, 6(7). https://doi.org/10.5539/elt.v6n7p1 


\section{Appendix A}

\section{Interview questions:}

1. What do you think good writing is?

2. What makes a good writer a good writer?

3. What are your goals for your students as writers?

4. How much time do you schedule for giving writing instruction?

5. What resources do you use when you teach writing?

6. Do you use multimedia and computers in teaching writing? If so, how? Do students use computers and multimedia comfortably when they complete writing projects? Talk about some examples of ways they use computers and multimedia.

7. What kinds of writing (genres) do you ask students to write? Which ones do you usually teach? How do you teach them?

8. How do you give feedback to your students on their writing? How important do you feel this feedback is in helping students with their writing?

9. Do students give feedback to each other on their writing? How important do you feel this feedback is in helping students with their writing?

10. What is unique about the students in your classroom that influences how you teach writing?

11. What are your students' strengths and weaknesses as writers?

12. What do you suggest that teachers should do to promote writing in the classroom?

\section{Copyrights}

Copyright for this article is retained by the author(s), with first publication rights granted to the journal.

This is an open-access article distributed under the terms and conditions of the Creative Commons Attribution license (http://creativecommons.org/licenses/by/4.0/). 